SAINTIFIK, Vol.5, No.1, Januari 2019, pp. 20 26

ISSN 2407-4098 (print)

ISSN 2622-8904 (online)

\title{
Meningkatkan Keterampilan Berpikir Kritis Melalui Pembelajaran Kooperatif Tipe Jigsaw Pada Mahasiswa Biologi STKIP PI Makassar
}

\author{
Kamriana $^{* 1}$, Nasrianty ${ }^{2}$ \\ ${ }^{1,2}$ STKIP PI Makassar \\ e-mail: *11 muflihah.sain@ gmail.com, ${ }^{2}$ nasriantyr@ymail.com
}

\begin{abstract}
Abstrak
Penelitian ini merupakan penelitian kuasi eksperimen dengan desain non-equivalent pretest-posttest control groupyang bertujuan untuk mengetahui pengaruh Pembelajaran KooperatifTipe Jigsaw terhadap Keterampilan Berpikir Kritis MahasiswaSTKIP Pembangunan Indonesia Makassar.Sampel dalam penelitian adalah mahasiswa Prodi Pendidikan Biologi STKIP Pembangunan Indonesia Makassar yang terdiri dari dua kelas dan berlaku sebagai kelompok eksperimen dan kelompok kontrol.Pengumpulan data dilakukan dengan observasi pada proses pembelajaran, Wawancara, nilai post tes serta dokumentasi.Observasi dilakukan dengan menggunakan lembar observasi pada saat proses pembelajaran. Nilai post test terdiri dari 10 pertanyaan essay secara keseluruhan.Teknik analisis data dilakukan dengan menggunakan statistik deskriptif kualitatif dan kuantitatif.
\end{abstract}

Kata kunci: Keterampilan Berpikir Kritis,Kooperatif Tipe Jigsaw, Pembelajaran

\section{PENDAHULUAN}

Pembangunan adalah pembangunan manusia dan seluruh masyarakat Indonesia seutuhnya dalam segala aspek. Pelaksanaan pembangunan menuntut keterlibatan semua pihak termasuk pemerintah dan masyarakat baik secara kelembagaan maupun perseorangan.Keterlibatan semua pihakutamanya pemerintah dapat meningkatkan potensi sumber daya manusia karena berkaitan dengan peningkatan pengetahuan, sikap, dan keterampilan, sehingga di masa akan dating dapat berpartisipasi secara aktif dalam pembangunan (Mulyana, 2008).

Seorang pendidik diharapkan mampu melakukan fungsinya dengan baik demi meningkatkan keaktifan peserta didik dalam mencapai tujuan pembelajaran. Proses belajar mengajar sangat ditentukan oleh minat, motivasi dan lingkungan belajar. Pembelajaran bermakna akan membuatpeserta didiklebih berpartisipasi dalam berbagai aktivitas kegiatan pembelajaran, sehingga peserta didik mampu mengaktualisasikan kemampuannya di dalam dan di luar kelas (Rusman, 2011). Berpikir kritis merupakan kemampuan yang berpengaruh bagi kehidupan seseorang kelak sehingga berpikir kritis akan membuat seseorang mengambil keputusan yang baik (Facione, 2011)

Kooperatif adalah bekerja bersama dalam mencapai tujuan bersama. Pembelajaran kooperatif merupakan istilah umum untuk sekumpulan strategi pengajaran yang dirancang untuk mendidik kerjasama kelompok dan interaksi antar peserta didik (Jacobs dkk, 2009). Pembelajaran kooperatif berfokus pada penggunaan kelompok kecil peserta didik untuk bekerja sama dalam memaksimalkan kondisi belajar untuk mencapai tujuan belajar (Suprijono, 2010). Pembelajaran kooperatif, belajar dikatakan belum selesai jika salah satu teman dalam kelompok 
belum menguasai bahan pelajaran (Malau, 2014).Kesimpulannya bahwa pembelajaran kooperatif merupakan strategi pembelajaran yang melibatkan peserta didik untuk bekerja secara kelompok untuk mencapai tujuan pembelajaran.

Model pembelajaran kooperatif tipe jigsaw merupakan model pembelajaran yang mampu mengajak peserta didik untuk berpikir secara aktif dan kreatif dalam proses pembelajaran. Model ini tidak hanya mengembangkan kemampuan intelektual tetapi seluruh potensi yang ada, termasuk pengembangan emosional dan pengembangan keterampilan (Budiawan dan Arsani, 2013).Ketika dihadapkan pada kondisi belajar seperti ini, peserta didik mempunyai kecenderungan untuk memberi arti pada masalah dan kejadian disekitarnya yang dapat memberi indikasi pada kemampuan berpikir yang dimiliki peserta didik.Kemampuan berpikir merupakan salah satu modal yang harus dimiliki peserta didik sebagai bekal dalam menghadapi perkembangan ilmu pengetahuan dan teknologi sebab keberhasilan seseorang bergantung pada kemampuan berpikirnya terutama dalam memecahkan masalah kehidupan yang dihadapinya (Ibrahim, 2007).

Selain itu, kemampuan berpikir juga sebagai sarana untuk mencapai tujuan pendidikan yaitu agar peserta didik mampu memecahkan masalah taraf tingkat tinggi (Nasution, 2008). guru perlu memilah untuk dapat menggunakan model pembelajaran lain sesuai dengan kebutuhan kelas yang akan diajar (Putra dan Hartati, 2014). Model pembelajaran kooperatif tipe jigsaw merupakan model pembelajaran yang mampu mengajak peserta didik untuk berpikir secara aktif dan kreatif dalam proses pembelajaran (Budiawan \& Arsani, 2013). Penggunaan model pembelajaran Jigsaw secara efektif dan efisien akan mengurangi monopoli pendidik dalam penguasaan jalannya proses pembelajaran, dan kebosanan peserta didik dalam menerima pelajaran akan berkurang (Lie, 2010).

Penelitian relevan bahwa model pembelajaran kooperatif tipe Jigsaw lebih baik daripada model konvensional (Budiawan dan Arsani, 2013).Pada dasarnya peserta didik mempunyai potensi kemampuan berpikir kritis dimana potensi ini sangat disayangkan jika tidak dapat dikembangkan dengan baik melalui penerapan model pembelajaran (Dwijananti dan Yulianti, 2010). Meningkatkan keterampilan berpikir kritis peserta didik melalui pembelajaran untuk praktek nyata dapat membantu peserta didik untuk mengembangkan pengetahuan dan keterampilan yang mereka akanbutuhkan untuk mencapai sukses di era informasi (Thaiposri dan Wannapiroon, 2015).

Rendahnya hasil belajarmahasiswa pada mata kuliah Botani Tumbuhan Rendah terjadi karena penyajiannya lebih sering menggunakanmetode ceramah. Pada metode ceramah, mahasiswa hanya mendengarkan dan mencatat apa yang dijelaskan oleh dosen sehingga keterampilan berpikir kritis dan perolehan tentang pemahaman konsep menjadi rendah, sebagai akibatnya mahasiswa tidak memahami konsep secara utuh dan hasil belajar pun rendah. Oleh karena itu, penelitian ini diharapkan dapat menjadi salah satu solusi dalam meningkatkan keterampilan berpikir kritis mahasiswa demi tercapainya hasil belajar yang diinginkan.

Hasil penelitian Hartati dan Sholihin (2015) menunjukkan bahwa terdapat perbedaan yang signifikan peningkatan kemampuan berpikir kritis siswa antara kelas yang menerapkan model pembelajaran dengan kelas kontrol. Kemampuan berpikir kritis siswa kelas eksperimen mengalami peningkatan sebesar $47 \%$ sedangkan peningkatan kemampuan berpikir kritis siswa kelas kontrol sebesar $32 \%$.

\section{METODE PENELITIAN}

Penelitian ini termasuk penelitian eksperimen yang bertujuan untuk mengetahui pengaruh pembelajaran kooperatif tipe Jigsaw terhadap keterampilan berpikir kritis mahasiswa STKIP Pembangunan Indonesia Makassar pada mata kuliah Anatomi Fisilogi Manusia. Penelitian ini dilaksanakan pada tahun 2018 di STKIP Pembangunan Indonesia Makassar.

Penelitian ini terdiri atas dua variabel, yaitu variabel terikat dan variabel bebas.Variabel terikat dalam penelitian ini yaitu Keterampilan Berpikir Kritis danvariabel bebas yaitu model pembelajaran kooperatif tipe Jigsaw. 
Rancangan yang digunakan dalam penelitian ini adalah seperti pada Tabel 1 berikut ini:

Tabel 1 Desain Penelitian

\begin{tabular}{|c|c|c|}
\hline Kelompok & Perlakuan & Posttes \\
\hline Eksperimen & $\mathrm{X}$ & $\mathrm{O}_{1}$ \\
\hline Kontrol & - & $\mathrm{O}_{2}$ \\
\hline
\end{tabular}

Keterangan:

$\mathrm{X}=$ Kelompok Perlakuan Pembelajaran Kooperatif Tipe Jigsaw

$\mathrm{O}_{1}, \mathrm{O}_{2} \quad=$ Post Tes

Populasi dalam penelitian ini adalah seluruh mahasiswaSTKIP Pembangunan Indonesia Makassar yang memprogramkan mata kuliah Anatomi Fisiologi Manusia. Pemilihan sampel dalam penelitian ini menggunakan teknik purposive sampling yang ditentukan dengan menetapkan semua mahasiswa yang memprogramkan mata kuliah Anatomi Fisiologi Manusiasebagai populasi penelitian dan memilih langsung 2 kelas untuk ditetapkan sebagai subjek penelitian dengan pertimbangan nilai hasil belajar, Semua mahasiswayang terpilih merupakan sampel dalam penelitian ini.

Sampel dibagi menjadi 2 kelas, 1 kelas merupakan kelompok uji dan 1 kelas sebagai kontrol. Kelompok uji diberikan perlakuan dengan model pembelajaran kooperatif tipe jigsaw dan kelas kontrol tidak diberikan perlakuan. Keterampilan Berpikir Kritis juga dapat dinilai berdasarkan tes hasil belajar. Tes hasil belajar dalam penelitian ini terdiri dari post tes, terdiri dari dan 10 soal essay untuk post tes. Rumus yang digunakan untuk menghitung nilai tes hasil belajar mahasiswasebagaiberikut:

Nilai $=\frac{\text { Skor Perolehan }}{\text { Skor Maksimal }} \times 100$

Pengelompokkan skor hasil belajar biologi mahasiswa merujuk pada pedoman pengkategorian hasil belajar menurutDepdiknas (2008) seperti pada Tabel 2 berikut:

Tabel 2 Skor Pengkategorian Hasil Belajar

\begin{tabular}{|l|l|}
\hline Interval Nilai & \multicolumn{1}{|c|}{ Kategori } \\
\hline $85-100$ & Sangat Tinggi \\
$65-84$ & Tinggi \\
$55-64$ & Sedang \\
$35-54$ & Rendah \\
$0-34$ & Sangat Rendah \\
\hline
\end{tabular}

Sumber: Depdiknas (2008)

\section{HASIL DAN PEMBAHASAN}

\subsection{Hasil Post Test}

Salah satu tolok ukur penelitian ini adalah hasil tes belajar. Tes diberikan kepada mahasiswa setelah proses pembelajaran selesai. Hasil tes belajar dapat dilihat pada Tabel 3 berikut.

Tabel 3 Kategori Hasil Post Test

SAINTIFIK Vol. 5, No. 1, Januari 2019: 20-26 


\begin{tabular}{|l|l|l|l|l|l|}
\hline Kategori & Eksperimen & $\%$ & Kontrol & $\%$ & Ket. \\
\hline $85-100$ & 13 & 48,15 & - & 0 & ST \\
\hline $65-84$ & 14 & 51,85 & 22 & 81,48 & T \\
\hline $55-64$ & - & 0 & 5 & 18,52 & S \\
\hline $35-54$ & - & 0 & - & 0 & R \\
\hline $0-34$ & - & 0 & - & 0 & SR \\
\hline
\end{tabular}

Berdasarkan persentase tes hasil belajar terdapat $48,15 \%$ mahasiswa yang mencapai nilai sangat tinggi dan 51,85\% nilai tinggi untuk kelas eksperimen, sedangkan pada kelas kontrol terdapat $81,52 \%$ yang mencapai nilai kategori tinggi dan $18,52 \%$ pada kategori sedang.

\subsection{Analisis Statistik}

\subsubsection{Uji Normalitas dan Homogenitas}

Descriptive Statistics

\begin{tabular}{|l|l|l|l|l|l|}
\hline & $\mathrm{N}$ & Mean & Std. Deviation & Minimum & Maximum \\
\hline EKSPERIME & 27 & 75,6296 & 13,15046 & 42,00 & 90,00 \\
$\mathrm{~N}$ & & & & & \\
KONTROL & 27 & 68,4074 & 5,08587 & 60,00 & 75,00 \\
\hline
\end{tabular}

One-Sample Kolmogorov-Smirnov Test

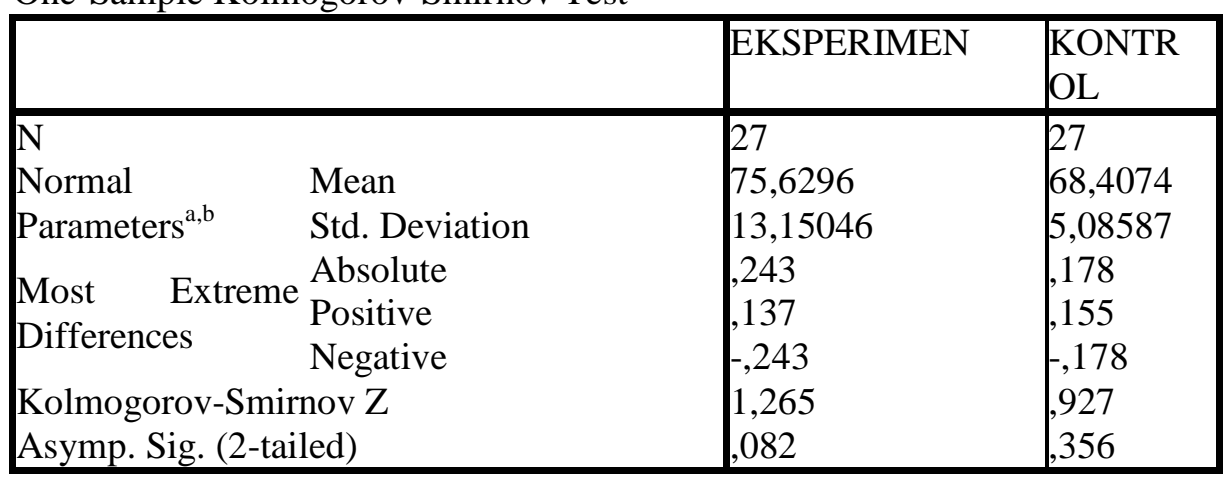

a. Test distribution is Normal.

b. Calculated from data.

\subsubsection{Uji Hipotesis}

One-Sample Statistics

\begin{tabular}{|l|l|l|l|l|}
\hline & & Mean & Std. Deviation & $\begin{array}{l}\text { Std. Error } \\
\text { Mean }\end{array}$ \\
\hline EKSPERIME & 27 & 75,6296 & 13,15046 & 2,53081 \\
$\mathrm{~N}$ & & 68,4074 & 5,08587 &, 97878 \\
KONTROL & 27 & & \\
\hline
\end{tabular}

One-Sample Test

Test Value $=0$ 


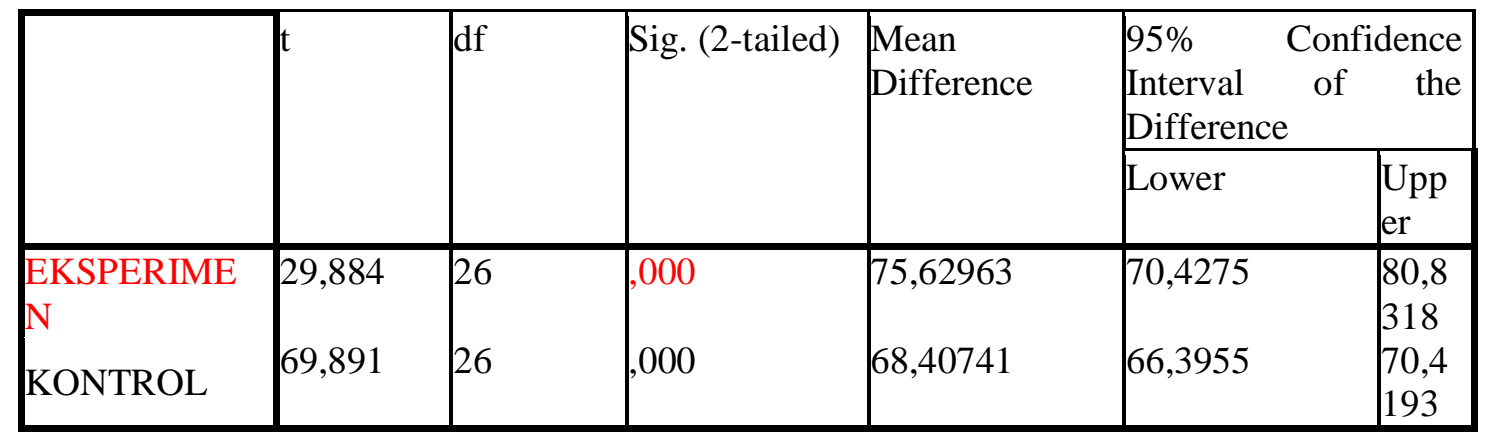

Keterangan: karena nilai sig (2-tailed) $<\alpha 0,05$, maka $\mathrm{H}_{0}$ ditolak dan $\mathrm{H}_{1}$ diterima yang berarti bahwa ada pengaruh pembelajaran kooperatif tipe jigsaw terhadap keterampilan berpikir kritis.

\subsection{Pembahasan}

Model pembelajaran cooperative learning merupakan salah satu pembelajaran yang mendukung pembelajaran konstektual.Pembelajaran cooperative learningmerupakan sistem kerja yang terstruktur yang merupakan suatu strategi belajar mengajar yang menekankan pada sikap atau perilaku bersama dalam bekerja yang teratur dalam kelompok, yang terdiri dua orang atau lebih.Pembelajaran cooperative learning tipe jigsaw adalah model pembelajaran dengan menggunakan pengkelompokkan yang terdiri antara empat, enam, bahkan sampai delapan orang yang mempunyai latar belakang yang berbeda.Sistem penilaian dilakukan terhadap kelompok dan setiap kelompok akan memperoleh penghargaan, jika kelompok dapat menunjukkan prestasi yang persyaratkan.

Model pembelajaran tipe jigsaw merupakan salah satu bagian dari model pembelajaran kooperatif yang dianggap dapat diterapkan dengan mudah dalam proses pembelajaran dan dapat memaksimalkan belajar siswa untuk meningkatkan akademik dan pemahaman baik secara individu maupun secara kelompok serta saling membantu satu sama lain (Trianto, 2009). Tes hasil belajar menunjukkan bahwa kelas eksperimen yang menggunakan model pembelajaran jigsaw memperolehnilai lebih baik jika dibandingkan dengan nilai pada kelas kontrol yang menggunakan pembelajaran langsung yang didominasi oleh ceramah dosen.

Berdasarkan hasil observasi terdapat beberapa mahasiswa yang aktif dalam model pembelajaran kooperatif tipe jigsaw. Meskipun mahasiswa tidak secara keseluruhan aktif namun kelas eksperimen ini jauh lebih aktif jika dibndingkan dengan kelas kontrol. Pada kelas kontrol mahasiswa terlihat kurang antusias dalam menerima pelajaran. Mahasiswa terlihat lebih sibuk dengan aktivitas masing-masing misalnya mengerjakan tugas mata kuliah lain, tetapi ada juga mahasiswa yang terlihat fokus memperhatikan penjelasan dosen.

Pada kelas eksperimen, semua mahasiswa aktif karena model pembelajaran tipe jigsaw mensyaratkan demikian dengan mengikuti langkah-langkah atau tahapan-tahapannya. Ketika sampai pada tahap diskusi, terlihat beberapa mahasiswa yang aktif bertanya dan menjawab, namun ada juga mahasiswa yang kurang aktif dalam diskusi meskipun hanya beberapa orang saja. Bahkan terdapat mahasiswa yang kurang aktif dalam diskusi namun ketika diberikan tes, hasil yang diperoleh tinggi. Hal tersebut menunjukkan bahwa pembelajaran tipe jigsaw tidak hanya membuat mahasiswa lebih aktif tetapi juga dapat memperbaiki nilai hasil belajar mahasiswa.

Terkait keterampilan berpikir kritis yang dapat diukur melalui tes dan lembar observasi menunjukkan bahwa pada umumnya mahasiswa memiliki keterampilan berpikir kritis yang baik, terbukti bahwa mereka dapat menjawab soal dengan baik berdasarkan pengetahuan yang mereka miliki namun benar dan ketika melakukan diskusi terkadang mereka berebutan untuk bertanya dan menjawab, berbeda pada kelas kontrol bahwa mahasiswa mempunyai nilai standar, tisak ada mahasiswa yang memiliki nilai kategori sangat tinggi meskipun dari mereka tidak ada yang memiliki nilai rendah.

Berdasarkan hasil wawancara yang dilakukan dengan beberapa mahasiswa, salah satu mahasiswa berpendapat bahwa pembelajaran tipe jigsaw ini adalah hal yang pertama kali

SAINTIFIK Vol. 5, No. 1, Januari 2019: 20-26 
dilakukannya selama kuliah, mahasiswa tersebut berpendapat bahwa tipe jigsaw ini membuatnya lebih antusias dan bersemangat tinggi dalam belajar, terbukti dengan nilai yang diperoleh oleh mahasiswa ini berada pada kategori sangat tinggi. Mahasiswa yang lain pun berpendapat demikian namun salah satu dari mereka berpendapat bahwa waktu yang digunakan cukup banyak sehingga hal tersebut bisa saja menjadi penghalang dilaksanakannya model pembelajaran ini. Namun semua mahasiswa berpendapat bahwa model pembelajaran ini dapat memicu cara belajar yang lebih baik.

Keterampilan berpikir kritis merupakan variabel laten yang tidak dapat diukur secara langsung seperti variabel fisik. Agar dapat mengukur karakteristik variabel laten, menurut Naga (2012: 13) dibutuhkan variabel manifes yang sepadan dengan variabel laten yang akan diukur. Pengukuran variabel manifes yang sepadan dengan variabel laten memerlukan suatu instrumen yang baku. Permasalahannya sekarang adalah bagaimana dosen dapatmemiliki instrumen baku tentang Keterampilan Berpikir Kritis, serta mampu melakukan pengukuran

Hal yang dikemukakan di atas sesuai dengan hasil analisis statistik yang menunjukkan bahwa nilai sig (2-tailed) $<\alpha 0,05$, maka $\mathrm{H}_{0}$ ditolak dan $\mathrm{H}_{1}$ diterima yang berarti bahwa ada pengaruh pembelajaran kooperatif tipe jigsaw terhadap keterampilan berpikir kritis. Ini menunjukkan bahwa penggunaan model pembelajaran tipe jigsaw dapat berpengaruh baik untuk peningkatan keterampilan berpikir mahasiswa.

Berdasarkan hasil penelitian dan pembahasan maka dapat dipahami bahwa proses pembelajaran yang dilakukan dalam penelitian tersebut dapat dijadikan sebagai pedoman dalam proses pembelajaran selanjutnya. Model pembelajaran yang berorientasi pada belajar dan bekerjasama antar peserta didik sangat banyak disajikan pada buku-buku model pembelajaran, pendidik hanya akan memilih beberapa model dalam proses pembelajaran yang dilakukannya, tentunya disesuaikan dengan situasi dan kondisi kelas. Setiap pendidik diharapkan mampu membuat peningkatan dalam belajar, baik moril maupun non moril.

\section{KESIMPULAN}

berikut:

Berdasarkan hasil analisis data dan pembahasan, maka diperoleh kesimpulan sebagai

1. Penggunaan model pembelajaran tipe jigsaw menunjukkan hasil lebih baik jika dibandingkan dengan pembelajaran ceramah

2. Nilai tes belajar yang diperoleh pada kelas eksperimen lebih tinggi dibandingkan nilai tes belajar pada kelas kontrol yaitu 48,15\% mahasiswa yang mencapai nilai sangat tinggi dan $51,85 \%$ nilai tinggi untuk kelas eksperimen, sedangkan pada kelas kontrol terdapat $81,52 \%$ yang mencapai nilai kategori tinggi dan $18,52 \%$ pada kategori sedang.

3. Nilai sig (2-tailed) $<\alpha 0,05$, maka $\mathrm{H} 0$ ditolak dan $\mathrm{H} 1$ diterima yang berarti bahwa ada pengaruh pembelajaran kooperatif tipe jigsaw terhadap keterampilan berpikir kritis.

\section{DAFTAR PUSTAKA}

Ali \& Abdurahman. 2009. Analisis Korelasi, Regresi, dan Jalur dalam Penelitian. Bandung: CV Pustaka Setia.

Anderson \& Krathwohl.2010. Pembelajaran Pengajaran dan Asessmen. Yogyakarta: Pustaka Belajar.

Arikunto. 2007. Dasar-Dasar Evaluasi Pendidikan Edisi Revisi. Jakarta: PT Bumi Aksara.

Besuki.2008. Pembelajaran Kooperatif Tipe Jigsaw.(online) http://edibesuki.blogspot.co.id/2008/11/pembelajaran-kooperatif-tipejigsaw_16.html.Diakses anggal 21 April 2016.

Browne \& Keeley. 2012. Pemikiran Kritis. Jakarta: Indeks

Budiawan \& Arsani. 2013. Pengaruh Model Pembelajaran Kooperatif Tipe Jigsaw dan Motivasi Belajar Terhadap Prestasi Belajar Ilmu Fisiologi Olahraga.Fakultas Olahraga dan Kesehatan 
Universitas Pendidikan Ganesha. Jurnal Pendidikan Indonesia ISSN: 2303-288X Vol. 2, No. 1, April 2013.

Depdiknas. 2008. Pengembangan Perangkat Penilaian. Jakarta: Departemen Pendidikan Nasional, Direktorat Jenderal Pendidikan Dasar dan Menengah.

Dwijananti \& Yulianti.2010. Pengembangan Kemampuan Berpikir Kritis Mahapeserta didik Melalui Pembelajaran Problem Basic Instruction pada Mata Kuliah Fisika Lingkungan. FMIPA UNNES. Jurnal Pendidikan Fisika Indonesia 6 (2010) 108-114. ISSN: 1693-1246, Juli 2010

Facione, P. 2011. Critical Thinking: What It Is and Why It Counts. (Online), (http://www.insightassessment.com), diakses tanggal 15 April 2016.

Hartati \& Sholihin. 2015.Meningkatkan Kemampuan Berpikir Kritis SiswaMelalui Implementasi Model Problem Based Learning (PBL) Pada Pembelajaran IPA Terpadu Siswa SMP. Prosiding Simposium Nasional Inovasi dan Pembelajaran Sains 2015 (SNIPS 2015) 8 dan 9 Juni 2015, Bandung, Indonesia

Ibrahim. 2007. Kecakapan Hidup: Keterampilan Berpikir Kritis. Surabaya: Universitas Negeri Surabaya.

Jacobsdkk. 2009. Metode-metode Pengajaran. Yogyakarta: Pustaka Belajar.

Kuswana. 2013. Taksonomi Berpikir. Bandung: Remaja Rosdakarya.

Lie. 2010. Cooperative Learning. Jakarta: Penerbit Grasindo.

Malau. 2014. Pembelajaran Kooperatif Tipe Jigsaw dalam Pembelajaran Fisika. Kementrian Pendidikan dan Kebudayaan Republik Indonesia. Jurnal Formatif 4(1): 1-10, 2014 ISSN: 2088-351X

Mulyana, E. 2008.Model Tukar Belajar (Learning Exchange) dalam perspektif Pendidikan Luar Sekolah (PLS). Bandung: Alfabeta.

Naga, Dali Santun. 2012. Teori Sekor padaPengukuran Mental. Jakarta:Nagarani Citrayasa.

Nasution.2008. Berbagai Pendekatan dalam Proses Belajar Mengajar.Jakarta : BumiAksara.

Putra \& Hartati. 2011. Penerapan Model Pembelajaran Kooperatif ipe Jigsaw terhadap Hasil Belajar Chest Past pada Permainan Bola Basket(Studi pada Peserta didik Kelas VII SMP Negeri 5 Sidoarjo). Jurnal Pendidikan Olahraga dan Kesehatan UNESA Volume 02 Nomor 03 Tahun 2014, 526 - 531526 ISSN : 2338-798X

Rahman. 2013. Model Kooperaif Jigsaw. (online)https://mahirbelajar.wordpress.com/2013/04/20/model-kooperatif-tipe-jigsaw/. Diakses tanggal 21 April 2016.

Rofiq. 2010. Pembelajaran Kooperatif (Cooperatif Learning dalam Pengajaran Pendidikan Agama Islam. JURNAL FALASIFA. Vol. 1 No. 1 Maret 2010

Rusman. 2011. Model-Model Pembelajaran, Pengembangang Profesinal Guru, edisi kedua. Jakarta : PT. Raja Grafindo Persada.

Sanjaya. 2008. Strategi Pembelajaran, Jakarta: Kencana Prenada.

Sjarkawi. 2006. Pembentukan Kepribadian Anak. Jakarta: Bumi Aksara.

Suprijono. 2009. Cooperative Learning Teori \& Aplikasi Paikem. Yogyakarta: Pustaka belajar.

Suprijono. 2010. Cooperative Learning. Yogyakarta: Pustaka Pelajar.

Thaiposri \& Wannapiroon. 2015. Enhancing students' critical thinking skills through teaching and learning by inquiry-based learning activities using social network and cloud computing. Faculty of Science and Technology, Nakhon Pathom Rajabhat University,Nakhon Pathom, 73000, Thailand, Faculty of Technical Education, King Mongkut's University of Technology North Bangkok, Bangkok, 10800, Thailand. Scient Direct.Procedia - Social and Behavioral Sciences 174 ( 2015 ) $2137-2144$.

SAINTIFIK Vol. 5, No. 1, Januari 2019: 20-26 